\title{
Access to Justice, \\ Civil Right to Counsel, and the Role of the Judge
}

\section{Russell Engler}

t

is hardly noteworthy to observe that judges play a crucial role in our adversary system, both inside and outside the courtroom. Yet, the past two decades have seen increased attention to the challenges facing the courts with the flood of unrepresented litigants in civil cases. The challenges impact the roles of each actor within the court system, including the judge. It should go without saying that the reality also creates immense challenges for the litigants themselves.

The challenges have led to an array of responses and strategies. Under the broad label of Access to Justice, responses have included a fundamental reexamination of how the courts should operate and how the various actors in the system may, or must, play their roles. Resolution 5 (2015) of the Conference of Chief Justices and Conference of State Court Administrations reaffirms the commitment to Meaningful Access to Justice for All, urging states to achieve the "goal of 100 percent access through a continuum of meaningful and appropriate services." Other initiatives focus on the need to go beyond more limited forms of assistance and establish a right to counsel in certain civil cases. The American Bar Association's landmark 2006 resolution calls for the provision of legal counsel as a matter of right "where basic human needs are at stake."2

With challenges come opportunities. This article therefore focuses on the crucial role of the judge not only in access to justice initiatives generally, but with a primary focus on the role of the judge in civil right to counsel issues. Judges will play a crucial role not only in enhancing access to justice, but also in helping to establish when a right to counsel is necessary to achieve access to justice, and often justice itself.

Part II sets the stage by exploring the access to justice and civil right to counsel backdrop for the discussion. Part III discusses the many ways in which judges are involved in civil right to counsel issues. Their role in deciding civil right to counsel issues that come before them is crucial, but by no means the full extent of their role. Judges also decide cases not directly addressing right to counsel issues but creating the opportunity to explain the context in which a right to counsel may be needed. At a more basic level, judges must engage thoughtfully with their role in helping to provide meaningful access to justice for unrepresented litigants appearing before them and unable to navigate the civil proceedings alone. Outside the courtroom, judges write articles, deliver speeches, participate in Access to Justice Commissions, support legislative measures, work on bench-bar initiatives to improve access to justice and even submit amicus briefs. They serve on commissions and committees that directly or indirectly demonstrate the need for a civil right to counsel in certain settings and support calls for such a right. Part IV places the right to counsel initiatives in the broader access to justice conversation, again highlighting the roles judges play in those initiatives.

\section{THE ACCESS TO JUSTICE AND CIVIL RIGHT TO COUNSEL BACKDROP}

\section{A. UNMET LEGAL NEEDS AND UNREPRESENTED LITIGANTS}

Court and bar leaders have struggled to respond to the phenomenon of unrepresented litigants flooding the courts. ${ }^{3}$ Legalneeds studies consistently show that roughly eighty percent of the legal needs of the poor go unaddressed. ${ }^{4}$ The Great Recession increased the numbers of Americans whose basic human needs are at issue in legal proceedings, and need counsel..$^{5}$ Even as the

\section{Author's Note:}

Professor of Law and Director of Clinical Programs, New England Law | Boston. I am grateful for the feedback I received from Judge David J. Dreyer, Clare Pastore, and John Pollock.

\section{Footnotes}

1. Conference of Chief Justices and Conference of State Court Administrators, Resolution 5: Reaffirming the Commitment to Meaningful Access to Justice for All (2015) (hereinafter "Resolution 5"), available at https://www.ncsc.org/ /media/Microsites/Files/access/5\%20 Meaningful\%20Access\%20to\%20Justice\%20for\%20All_final.ashx.

2. Am. Bar Ass'n, Resolution 112A (2006) (hereinafter "ABA Resolution 112A"), available at http://abanet.org/leadership/2006/annual/onehundredtwelvea.doc.

3. Unrepresented litigants also are referred to as "self-represented" or "pro se" litigants, among other terms. In the contexts discussed in this article, I believe the word "unrepresented" is more accurate, since many litigants lack power and a voice in the legal system and should be viewed as without representation, rather than as choosing to forgo hiring a lawyer. For a further explanation of why I believe the term "unrepresented litigants" is more appropriate than "selfrepresented litigants," see Russell Engler, And Justice for AllIncluding the Unrepresented Poor: Revisiting the Roles of the Judges, Mediators and Clerks, 67 FordHAM L. REv. 1987, 1992, n. 23 (1999).

4. Legal Servis. Corp., Documenting the Justice Gap in America: The Current Unmet Civil Legal Needs of Low-Income Americans (2017) [hereinafter Legal Servs. CorP., Documenting 2017], available at https://www.lsc.gov/sites/default/files/images/TheJusticeGapFullReport.pdf (" $86 \%$ of the civil legal problems reported by lowincome Americans in the past year received inadequate or no legal help." Id., at 6).

5. Legal Servis. Corp., Documenting the Justice Gap in America: The Current Unmet Civil Legal Needs of Low-Income Americans 5 (2009), available at https://www.lsc.gov/sites/default/files/LSC/pdfs/ documenting_the_justice_gap_in_america_2009.pdf (hereinafter Legal Servs. Corp., Documenting 2009) ("The current economic cri- 
economy improved, the legal needs of poor and moderate income households continue to grow. Many unmet legal needs involve housing, family, and consumer issues. ${ }^{6} \mathrm{~A}$ related trend is the shortage of available and affordable legal services. Legal services offices represent only a fraction of eligible clients seeking assistance. ${ }^{7}$ The same funding crisis that expanded the numbers of those needing help during the Great Recession decimated the ability of legal services offices to provide assistance. ${ }^{8}$ Even with increased funding in some states in recent years, the vast majority of legal needs go unmet. ${ }^{9}$

With a high incidence of unmet legal needs and a shortage of lawyers for the poor, unrepresented litigants flood the courts in civil cases. Most family law cases involve at least one party without counsel, and often two. ${ }^{10}$ The vast majority of tenants, some landlords, and most debtors appear in court without counsel. ${ }^{11}$ Unrepresented litigants disproportionately are minorities and typically are poor. ${ }^{12}$ They often identify an inability to pay for a lawyer as the primary reason for appearing without counsel. ${ }^{13}$ The consequences of appearing without counsel are devastating, since unrepresented litigants often fare poorly in the courts. Studies and accounts suggest that representation can be a crucial variable impacting case outcomes in eviction, custody, debt-collection, and benefits proceedings. ${ }^{14}$

\section{B. THE SURGE IN CIVIL RIGHT TO COUNSEL AND ACCESS TO JUSTICE ACTIVITY}

These trends have given rise both to a renewed interest in achieving a right to counsel in certain civil settings and in a renewed commitment to access to justice more generally. Activity supporting a civil right to counsel increased sharply after 2003, the fortieth anniversary of Gideon v. Wainwright. ${ }^{15}$ Articles, ${ }^{16}$ conferences, ${ }^{17}$ and speeches ${ }^{18}$ addressed the issue, while membership increased in the newly formed National Coalition for a Civil Right to Counsel (NCCRC). 19 Advocates pursued test $\operatorname{cases}^{20}$ and legislative strategies, ${ }^{21}$ attempting to establish the right to counsel. In 2006, the American Bar Association (ABA) unanimously adopted Resolution 112A, urging the provision of "legal counsel as a matter of right at public expense to low income persons in those categories of adversarial proceedings where basic human needs are at stake, such as those involving shelter, sustenance, safety, health or child custody," as determined by each jurisdiction. ${ }^{22}$ Many states and cities launched pilot projects to test the efficacy of innovations. ${ }^{23}$ In 2017, New York City adopted a right to counsel for indigent tenants facing eviction through its Universal Access program, with impressive first-year results. ${ }^{24}$ San Francisco, Newark, Cleveland, Philadelphia, and Santa Monica have announced the sis, with its attendant problems of high unemployment, home foreclosures and family stress, has resulted in legal problems relating to consumer credit, housing, employment, bankruptcies, domestic violence and child support, and has pushed many families into poverty for the first time.").

6. Legal Servis. Corp., Documenting 2017, supra note 5, at 23-24.

7. See Alan W. Houseman, The Future of Legal Aid: A National Perspective, 10 UDC L. REV. 35, 43-46 (2007).

8. See Legal Servis. Corp., Documenting 2009, supra note 5, at 5-8.

9. See Legal Servis. Corp., Documenting 2017, supra note 4, at 42-45. "Low-income Americans will receive insufficient or no legal help for an estimated 1.1 million eligible problems this year alone." Id, at 45. "A lack of available resources accounts for the vast majority of eligible civil legal problems that go unserved or underserved." Id.

10. See, e.g., Russell Engler, Connecting Self-Representation to Civil Gideon: What Existing Data Reveal About When Counsel Is Most Needed, 37 Fordham URB. L.J. 37, 41 (2010) (hereinafter "Connecting Self-Representation to Civil Gideon").

11. Id.

12. Id.

13. Id.

14. Id., at 46-66.

15. 372 U.S. 335 (1963)

16. See, e.g., Laura K. Abel, A Right to Counsel in Civil Cases: Lessons from Gideon v. Wainwright, 15 Temp. Pol. \& Civ. RTS. L. Rev. 527 (2006); Symposium, A Right to a Lawyer? Momentum Grows, 40 Clearinghouse Rev. 163 (2006); Symposium Issue, A Right to Counsel in Civil Cases: Civil Gideon in Maryland E Beyond, 37 U. BALT. L. REv. 1-77 (2007).

17. For example, the Sparer Symposium held on March 28, 2006, was titled "Civil Gideon: Making the Case." The Temple Politica and Civil Rights Law Review published papers presented at the conference in its symposium issue Civil Gideon: Creating a Constitutional Right to
Counsel in the Civil Context, 15 Temp. Pol. \& Civ. RTS. L. Rev. 501800 (2006). The inaugural Symposium of the University of Baltimore Law Review, held on April 5, 2007, was dedicated to the topic of A Right to Counsel in Civil Cases: Civil Gideon in Maryland and Beyond, producing the Symposium issue at supra, note 16. Leigh Goodmark, Forward, a Right to Counsel in Civil Cases: Civil Gideon in Maryland and Beyond, 37 U. BALT. L. Rev. 1 (2007).

18. See, e.g., Earl Johnson, Jr., Three Phases of Justice for the Poor: From Charity to Discretion to Right, 43 Clearinghouse Rev. 486 (2009).

19. See, e.g., Paul Marvy \& Debra Gardner, A Civil Right to Counsel for the Poor, Hum. RTS., Summer 2005, at 8, 9. The Coalition's website is an invaluable resource on the topic, with information about cases, articles, speeches, conferences at which the Coalition has participated-http://civilrighttocounsel.org/.

20. See, e.g., Frase v. Barnhart, 840 A.2d 114 (Md. 2003)(hereinafter "Frase"); King v. King, 174 P.3d 659 (Wash. 2007) (en banc)( hereinafter "King"); Kelly v. Warpinski, No. 04-2999-OA (Wis. Apr. 6, 2005)( hereinafter "Kelly").

21. See, e.g., Laura K. Abel \& Max Rettig, State Statutes Providing for Right to Counsel in Civil Cases, 40 Clearinghouse Rev. 245 (2006); Paul Marvy \& Laura Klein Abel, Current Developments in Advocacy to Expand the Civil Right to Counsel, 25 Touro L. REv. 131, 132-33 (2009).

22. ABA Resolution 112A, supra note 2 .

23. See, http://civilrighttocounsel.org/highlighted_work/pilot_projects.

24. The New York City Right to Counsel Coalition website provides information about the history of the bill, its coverage, and how the legislation operates-https://www.righttocounselnyc.org/. The New York City's Office of Civil Justice Report on the first year of operation of the program is available online at https://wwwl.nyc.gov/ assets/hra/downloads/pdf/services/civiljustice/OCJ-UA-2018Report.pdf. 


\section{"Over the past two decades, access to justice initiatives have proliferated..."}

creation of comparable rights, while other jurisdictions are exploring a similar step..$^{25}$

The same trends that spurred increased activity in pursuing a civil right to counsel gave rise to a renewed commitment to access to justice. Over the past two decades, access to justice initiatives have proliferated, spurred by conferences dedicated to the topic. 26 Conferences of judges and state court administrators have adopted resolutions calling for the courts to provide meaningful access to justice. ${ }^{27}$ The number of state access to justice commissions increased rapidly; sixteen states created commissions between 2003 and 2008.28 The commissions "are collaborative entities that bring together courts, the bar, civil legal aid providers, and other stakeholders in an effort to remove barriers to civil justice for low-income and disadvantaged people."29 Approximately 40 states have Commissions, or other Access to Justice entities.30 The Justice Index of the National Center for Access to Justice collects, tabulates, and presents data measuring the commitment of states to access to justice and allowing them to share achievements. 31

\section{SCHOLARSHIP AND EMPIRICAL WORK}

The scholarly attention to civil right to counsel and access to justice topics has increased dramatically.32 The Winter 2019 issue of Daedelus was devoted entirely to the topic of access to justice. The twenty-four essays included in the volume illustrate the breadth of topics under the broad label of access to justice:

"Access to Justice"-the first open access issue of Dadalus-features twenty-four essays that examine the national crisis in civil legal services facing poor and lowincome Americans: from the challenges of providing quality legal assistance to more people, to the social and economic costs of an often unresponsive legal system, to the opportunities for improvement offered by new technologies, professional innovations, and fresh ways of thinking about the crisis. 33

With respect to civil right to counsel scholarship, the comprehensive bibliography of the National Coalition for a Civil Right to Counsel's website includes almost 400 articles. ${ }^{34}$

Initiatives that form the access to justice backdrop often have been accompanied by efforts to develop data to evaluate the work. With the increased use of hotlines and the development of pro se clinics and self-help centers, reports emerged describing the initiatives, reporting data and evaluating their success. ${ }^{35}$ The late Richard Zorza's Access to Justice Blog often included reports of such efforts. ${ }^{36}$ The National Center for Access to Justice developed the Justice Index as a tool to begin to measure access to justice and allow for comparisons across jurisdictions. ${ }^{37}$ The Center recently announced the creation of an Access to Justice Scholarship Project to focus on "growing the field of AtJ scholarship and building an agenda for AtJ research by identifying scholars doing pertinent work in diverse fields." 38

An important component of the research includes efforts to
25. The "Status Map" on the website of the National Coalition for a Civil Right to Counsel is an invaluable resource for keeping abreast of the fast-changing landscape. See, http://civilrighttocounsel.org/map (subject area "Housing-Evictions"). As the status map reflects, jurisdictions are adopting the right by different vehicles. For example, San Francisco adopted the right to counsel by ballot initiative in June 2018. See, http://civilrighttocounsel.org/major_developments/1179. Legislation to establish a right to counsel for evictions (with varying income limits or other limitations in certain jurisdictions) has been introduced in Connecticut, Massachusetts, Minnesota, and Los Angeles. See, e.g., http://www.massrtc.org/ national.html

26. For example, the State Access to Justice Commission chairs now meet annually, under the auspices of the American Bar Association's Section on Legal Aid and Indigent Defense. See, e.g., https://www.americanbar.org/groups/legal_aid_indigent_defendants/resource_center_for_access_to_justice/annual_meeting/.

27. The Conference of Chief Justices (CCJ) has adopted over 40 resolutions relating to access to justice. See, https://ccj.ncsc.org/Policy-Resolutions.aspx.

28. Karla M. Gray \& Robert Echols, Mobilizing Lawyers, Judges, and Communities: State Access to Justice Commissions, Judges' J., Summer 2008, at 33, 35-36.

29. See https://www.americanbar.org/groups/legal_aid_indigent_defendants/resource_center_for_access_to_justice/atj-commissions/.

30. See https://www.americanbar.org/groups/legal_aid_indigent_defendants/resource_center_for_access_to_justice/atj-commissions/commission-directory/ (ABA Directory of Current Commissions and their structure).

31. See https://justiceindex.org/.
32. For example, Westlaw searches reveal that the number of articles with "Access to Justice" in the title jumped from 16 in 2003 to 51 in 2018. Compare, search results of DA(aft 12-31-2002 \& bef 01-012004) \& TI("Access \#to Justice") with DA(aft 12-31-2017 \& bef 0101-2019) \& TI("Access \#to Justice"). Search performed July 23, 2019. Rebecca Sandefur has noted that "[a]fter a flowering in the 1970's and early 1980's, basic research into access to civil justice fragmented into a number of highly specialized literatures across law and the social science disciplines," something the recent scholarly focus has tried to address. Rebecca L. Sandefur, P.I., Access to Civil Justice: Re-envisioning and Reinvigorating Research, a Workshop, submitted to and funded by the National Science Foundation (SES1237958) (2012), Project Summary, at 1 (on file with author).

33. See https://www.amacad.org/daedalus/access-to-justice.

34. See http://civilrighttocounsel.org/resources/bibliography/comprehensive_bibliography.

35. Connecting Self-Representation to Civil Gideon, supra note 11, at 66-73.

36. See Richard ZorzA's Access to Justice Blog, available at http://accesstojustice.net.

37. The Justice Index's website is available at https://justiceindex.org/.

38. See https://ncforaj.org/2018/08/03/national-science-foundationannounces-atj-scholarship-project-naming-rebecca-sandefur-principal-investigator-and-alyx-mark-david-udell-co-principal-investigators/. The project, funded by the National Science Foundation, brought together scholars for an intensive workshop in June 2019, as part of a project to produce a census-style survey of academic disciplines engaged in access-to-justice scholarship. See also, https://nsf.gov/awardsearch/showAward?AWD_ID=1823791\&HistoricalAwards=false. 
evaluate the impact of counsel, as well as the effectiveness of more limited forms of assistance, including self-help programs. 39 Not all the research has been met with open arms by those working in the access to justice and civil right to counsel communities. For example, some empirical work raised questions about the validity of previous studies on which many widely held views about the importance of lawyers rested. 40 At the same time, some empirical work raised questions about the effectiveness of limited assistance or self-help programs. ${ }^{41}$ Critics questioned whether the data actually supported the conclusions being proffered or the methodologies used were valid.42 Other scholars focus instead on limitations as to what the studies show us even where valid. ${ }^{43}$ A different thread of research focuses on the economic benefits that flow from provision of effective legal assistance, including full representation by counsel. 44

It is beyond the scope of this article to explore the scholarly debate over what lessons to draw from the body of empirical work. I have analyzed elsewhere how the effectiveness of representation relates to a variety of factors beyond simply whether a party has a lawyer. 45 Those factors include: the representatives and the tactics they use; the forum, including the judge or hearing officer, and the court or agency; the applicable law, both procedural and substantive; the alternatives to full representation in a particular setting; and the litigants. 46 Those variables combine to underscore the crucial role of power and power imbalances in the legal system. They also provide important clues as to the settings in which full representation by a skilled advocate-and often a right to counsel-is likely to be needed to provide meaningful access and those in which other forms of assistance might suffice. ${ }^{47}$

\section{CIVIL RIGHT TO COUNSEL AND ROLES FOR JUDGES}

\section{A. CASES}

The United States Supreme Court's 2011 decision in Turner v. Rogers $^{48}$ sets forth the fourteenth amendment framework govern-
39. For a discussion a much of the empirical work in the area, see generally, Connecting Self-Representation to Civil Gideon, supra note 11. See also, Russell Engler, When Does Representation Matter? in Beyond Elite LaW: Access to Civil Justice in AmericA, 71, 86 (Samuel Estreicher \& Joy Radice eds., 2016). Rebecca Sandefur's important research in the area relies on meta-analysis, studying a series of reports that allow her to draw conclusions across substantive areas. See, e.g., Rebecca L. Sandefur, The Impact of Counsel: An Analysis of Empirical Evidence, 9 SEATtLE J. FOR SOC. Just. 51, 5152 (2011); Rebecca L. Sandefur, Money Isn't Everything: Understanding Moderate Income Households Use of Lawyers' Services, in Middle Income Access to Justice 223, 223 (Michael J. Trebilcock, Anthony J. Duggan \& Lorne Mitchell Sossin eds., 2012); Rebecca Sandefur, Elements of Professional Expertise: Understanding Relational and Substantive Expertise through Lawyers' Impacts, 80 Aм. SOC. REV. 909-933 (2015).

40. Recent empirical work involving randomized control studies suggests that the correlation between full representation and case outcomes is not clear in all settings or that non-randomized students are not persuasive. See D. James Greiner \& Cassandra Wolos Pattanayak, Randomized Evaluation in Legal Assistance: What Difference Does Representation (Offer and Actual Use) Make, 121 YALE L.J. 2118, 2178-96 (2012).

41. See, e.g., Jessica K. Steinberg, In Pursuit of Justice? Case Outcomes and the Delivery of Unbundled Legal Services, 18 GEO. J. POV. LAW \& POL'Y 453, 463 (2011); D. James Greiner et al., The Limits of Unbundled Legal Assistance: A Randomized Study in a Massachusetts District Court and Prospects for the Future, 126 HARV. L. REV. 901 (2013).

42. For example, Ross Dolloff challenged a hotline outcome assessment prepared for the Legal Services Corporation that reported favorable outcomes for a majority of cases, contending that the data, properly read, instead showed a success rate of less than 8\%. Ross Dolloff, Let's Talk About Values, Not Systems, Mgmt. Info. Exchange J., Summer 2003, at 41. Steinberg's study comparing outcomes in cases with full representation to those involving limited assistance showed that while the unbundled assistance showed benefits in certain process outcomes, those same litigants received less favorable outcomes on the merits. Steinberg, supra note 41. Critics of the Greiner and Pattanayak randomized control study of unemployment cases, supra note 40 , maintained that the studies failed to shed light on the impact of representation by counsel, since nearly half the control group actu- ally received representation, often by a legal services office. See Bob Sable, What Difference Representation-a Response, CONCURRING Opinions, Mar. 28, 2011, available at https://bit.ly/2ULbawI.

43. See, e.g., Catherine R. Albiston \& Rebecca L. Sandefur, Expanding the Empirical Study of Access to Justice, Wisc. L. REv. 101, 106-09 (2013). Albiston and Sandefur argue that randomized control trials are an important contribution to the field, but still leave questions unanswered. First, while the studies may reveal interventions that demonstrate improved outcomes, they do not show why the outcomes are improved. Second, where the studies do not show a statistically significant correlation between a variable and an outcome, "an absence of evidence does not mean evidence of the absence of a relationship." Third, a study focused on individual outcomes will not shed light on potential systemic benefits of representation, such as to others beyond the individuals, or the legal system. Id.

44. See, e.g., Laura K. Abel \& Susan Vignola, Economic and Other Benefits Associated with the Provision of Civil Legal Aid, 9 SEATTLE J. FOR Soc. Just. 139 (2010). Massachusetts, New York City, and Philadelphia are among the jurisdictions that have produced studies showing the costs savings from providing representation for tenants in eviction cases. See, Statewide Task Force to Expand Civil Legal Aid in Massachusetts, Investing in Justice: A Roadmap to Cost EfFective Funding of Civil Legal Aid in Massachusetts, 17-20 (Boston Bar Association 2014) (hereinafter "INVESTING IN JusTiCE"), available at http://www.bostonbar.org/docs/default-document-library/ statewide-task-force-to-expand-civil-legal-aid-in-ma-investing-injustice.pdf; The Financial Cost and Benefits of Establishing a Right to Counsel in Eviction Proceedings Under Intro 214-A (March 16, 2016) is available at https://www2. nycbar.org/pdf/ report/uploads/SRR_Report_Financial_Cost_and_Benefits_of_Estab lishing_a_Right_to_Counsel_in_Eviction_Proceedings.pdf; Economic Return on Investment of Providing Counsel in Philadelphia Eviction Cases for Low-Income Tenants, Prepared for the Philadelphia Bar Association's Civil Gideon and Access to Justice Task Force (November 2018), available at https://www.philadelphiabar.org/ WebObjects/PBA.woa/Contents/WebServerResources/CMSResources/PhiladelphiaEvictionsReport.pdf.

45. Engler, When Does Representation Matter?, supra note 39

46. Id., at 80-84.

47. Id., at 84-85.

48. 131 S. Ct. at 2513 (2011) (hereinafter "Turner"). 


"[T] ${ }^{\mathrm{T} e r e ~ w a s ~}$
no categorical
right to counsel
as a matter of
federal due
process law in
termination of
parental rights
proceedings."

ing right to counsel decisions in civil cases. Turner relied in its analysis on the Court's decision thirty years before in Lassiter v. Department of Social Services. 49 This section describes the Lassiter and Turner decisions before turning to state court decisions.

\section{i. Lassiter v. Department of Social Services}

In the wake of the landmark case of Gideon v. Wainwright ${ }^{50}$ and its progeny, the United States Supreme Court did extend the right to counsel to certain civil settings. ${ }^{51}$ The hope that the Court might continue to extend the categorical right to counsel to other civil settings was dealt a devastating blow with the Court's 1981 Lassiter decision. The Court's decision came only two years after the European Court of Human Rights construed a provision requiring a "fair and public hearing" to require appointment of civil counsel in an action for marital separation. .52

Lassiter held that due process under the United States Constitution did not require a categorical right to counsel for a parent facing termination of parental rights. ${ }^{53}$ Under Lassiter, whether a litigant is entitled to counsel as a matter of due process turns on the application of the familiar Mathews v. Eldridge ${ }^{54}$ test to the particular case. ${ }^{55}$ The Mathews test, relied upon by the court in Lassiter and later in Turner, requires consideration of "(1) the nature of 'the private interest that will be affected,' (2) the comparative 'risk' of an 'erroneous deprivation' of that interest with and without 'additional or substitute procedural safeguards,' and (3) the nature and the magnitude of any countervailing interest in not providing 'additional or substitute requirement[s]."'56 Applying the Mathews factors, a bitterly divided court held that there was no categorical right to counsel as a matter of federal due process law in termination of parental rights proceedings. ${ }^{57}$

In dissent, Justice Blackmun criticized the majority for avoiding "what seems to me the obvious conclusion that due process requires the presence of counsel for a parent threatened with termination of parental rights," reviving "an ad hoc approach thoroughly discredited nearly 20 years ago in Gideon v. Wainwright...." 58 Although the majority and dissent both follow a "markedly similar" analysis in analyzing the three Mathews factors, "the Court abruptly pulls back" and calls for a case-by-case analysis, rather than an analysis of different contexts; "[t]his conclusion is not only illogical, but it also marks a sharp departure from due process analysis consistently applied heretofore." 59 The dissent sets forth in detail the difficulties the petitioner faced attempting to represent herself, and notes the difficulty and exasperation the trial court experienced in conducting the hearing, which Justice Blackmun attributed "in large measure, if not entirely, to the lack of counsel." The dissent found "virtually incredible the Court's conclusion today that her termination proceeding was fundamentally fair." 60

Lassiter at most establishes a presumption under the fourteenth amendment against a categorical right to counsel in civil cases where physical liberty is not at stake. Courts following Lassiter were still obligated to determine whether the facts of a particular case required appointment of counsel. Yet, "[i]n practice, Lassiter sounded a death knell for efforts to recognize a meaningful civil right to counsel as a matter of federal due process." 61

\section{ii. Turner v. Rogers}

Thirty years after Lassiter, the Court stepped back into the civil right to counsel fray in Turner v. Rogers. Turner involved the appeal of the defendant, Michael Turner, who had been held in civil contempt for his failure to make child support payments to unrepresented plaintiff, Rebecca Rogers, the mother of their child. ${ }^{62}$ Turner repeatedly failed to pay the amount due and was sentenced on numerous occasions to imprisonment for failure to
49. 452 U.S. 18 (1981) (hereinafter "Lassiter").

50. 372 U.S. 335 (1963).

51. See, e.g., In re Gault, 387 U.S. 1 (1967) (holding that due process in "juvenile delinquency" proceedings includes the right for the child and his or her parents to be represented by counsel and to have counsel appointed if they cannot afford counsel); see also Vitek v. Jones, 445 U.S. 480, 100 S.Ct. 1254 (1980)(finding a right to assistance of a qualified representative when prisoners are transferred to mental health facilities). Four justices believed that "it is appropriate that counsel be provided to indigent prisoners whom the State seeks to treat as mentally ill." 44 S.Ct. at 498. Justice Powell, providing the fifth vote, agreed that "qualified independent assistance must be provided," but believed that the requirement did not always demand "that a licensed attorney be provided." Id.

52. Airey v. Ireland, 2 Eur. Ct. H.R. (ser. A) 305, 309 (1979). The Airey Court construed Article 6 of the European Convention for the Protection of Human Rights and Fundamental Freedoms in reaching its result. Some commentators have interpreted Airey as recognizing a right to counsel in civil cases. See, e.g., Earl Johnson, Jr., Will Gideon's Trumpet Sound a New Melody? The Globalization of Constitutional Values and its Implications for a Right to Equal Justice in Civil Cases, 2 Seattle J. For Soc. Just. 201 (2003) (interpreting Airey as holding that the guarantee of a "fair hearing" in civil cases required the government to provide free counsel to indigent civil litigants). A more nuanced interpretation reads Airey as determining that Article 6 requires "effective access to the court," which means "representation by an attorney, or a proceeding simple enough that a layperson could handle it without a lawyer." Raven Lidman, Civil Gideon: A Human Right Elsewhere in the World, 40 Clearinghouse Rev. 288, 290-91 (July-August 2006).

53. See Lassiter, supra note 49.

54. 424 U.S. 319 (1976) (hereinafter "Mathews").

55. See id. at 27-31.

56. Turner, supra note 48, at 2517-18 (quoting Mathews, 424 U.S. at 335).

57. See, Lassiter, supra note 49, at 27-34.

58. Id. at 35 .

59. Id., at 49.

60. Id, at 56-57. Dissenting separately, Justice Stevens agreed with the conclusion reached by Justice Blackmun that the Mathews analysis requires appointment of counsel in this type of case, but also believed that "issue is one of fundamental fairness, not of weighing the pecuniary costs against societal benefits." Id, at 60 .

61. Paul Marvy \& Debra Gardner, A Civil Right to Counsel for the Poor, Hum. RTS., Summer 2005, at 8.

62. Turner, supra 48, at 2513.

14 Court Review - Volume 56 
pay; Turner was jailed three times, the final time for a year. 63 Turner was unrepresented at his civil contempt hearings but, while incarcerated, retained a pro bono attorney to challenge the failure of the South Carolina court to appoint counsel for him. ${ }^{64}$ On appeal, a unanimous Supreme Court held that the Due Process Clause did not automatically require appointment of counsel on the facts presented.

Relying on Lassiter, the majority applied the Mathews test to the Turner facts. ${ }^{65}$

The majority first found that the freedom from bodily restraint, the private interest affected, "argues strongly for the right to counsel that Turner advocates." 66 However, the Court declined to hold that the balance of factors required appointment of counsel in all civil contempt proceedings involving child support in which incarceration is threatened for three reasons. First, on the critical issue of the defendant's ability to pay the underlying obligation, "when the right procedures are in place, indigence can be a question that in many-but not all_cases is sufficiently straightforward to warrant determination prior to providing a defendant with counsel." 67 Second, since the person opposing the defendant was "not the government represented by counsel but the custodial parent unrepresented by counsel," the Court noted that a requirement that the state provide counsel to the alleged contemnor "could create an asymmetry of representation that would 'alter significantly the nature of the proceeding"'; the Court felt that doing so might not only mean "a degree of formality or delay that would unduly slow payment" but also "could make the proceedings less fair overall, increasing the risk of a decision that would erroneously deprive a family of the support it is entitled to receive." 68

Third, the Court believed that "there [was] available a set of 'substitute procedural safeguards' ... which, if employed together, [could] significantly reduce the risk of an erroneous deprivation of liberty" without incurring drawbacks inherent to an automatic right to counsel. 69 The Court identified four such safeguards: notice to the defendant that his "ability to pay" is a critical issue [in the contempt proceeding]

; (2) the use of a form (or the equivalent) to elicit relevant financial information an opportunity [for a] hearing for [the defendant] to respond to statements and questions about his financial status; and (4) an express finding by the court that the defendant has the ability to pay. ${ }^{70}$

The majority concluded that, since the "record indicate[d] that Turner received neither counsel nor the benefit of alternative procedures" like those the majority had described, Turner's incarceration violated the Due Process Clause. ${ }^{71}$

\section{iii. Categorical Rights under State Law}

With Lassiter and Turner illustrating the Supreme Court's reluctance to recognize a federal due process categorical right to counsel the civil cases before it, the expansion of the right to counsel has occurred almost exclusively at the state and local levels. States have passed hundreds of laws and court rules guaranteeing the right to counsel in civil cases, including in family law, involuntary commitment, and medical treatment cases. ${ }^{72}$ The recent trend creating a right to counsel in eviction cases has occurred at the city level, by ordinance or ballot initiative. ${ }^{73}$ The NCCRC website tracks the status of current bills through a variety of tools. ${ }^{74}$ As discussed below, judges play important roles in furthering and supporting legislative initiatives.

The more direct way that judges have been involved in the expansion of the civil right to counsel, of course, is in their decisions from the bench. Clare Pastore has provided an overview of state right to counsel decisions. ${ }^{75}$ The cases most easily accessed
63. Id. at 2513-14.

64. Id.

65. Turner, supra note 48, at 2517.

66. Id. at 2518 .

67. Id. at 2519.

68. Id. at 2519 (quoting Gagnon v. Scarpelli, 411 U.S. 778, 787 (1973)).

The Court explicitly noted that it was not addressing "civil contempt proceedings where the underlying child support payment is owed to the State." Id., at 2520.

69. Id. (quoting Mathews, 424 U.S. at 335).

70. Id.

71. Id. at 2520. The four-person dissent would have ended the analysis with the holding that the Due Process Clause did not automatically require appointment of counsel on the facts presented, rather than include the Court's discussion of what safeguards might obviate the need for counsel in some or all cases. "The only question raised in this case is whether the Due Process Clause of the Fourteenth Amendment creates a right to appointed counsel for all indigent defendants facing incarceration in civil contempt proceedings. It does not." Id. at 2521 (Thomas, J., dissenting). Recent empirical work from South Carolina casts doubt on whether the "substitute procedural safeguards" envisioned by the majority in fact provide the needed safeguards, since the changes adopted by South Carolina after Turner did not appear "to increase[] the accuracy of the decisions concerning ability to pay or alter[] the outcome in cases where the obligor lacked the ability to pay." Elizabeth G. Patterson, Turner in the Trenches: A Study of How Turner v. Rogers Affected Civil Contempt Proceedings, 25 GEO. J. ON POVERTY L. POL'y 75, 113 (2017).

72. Laura K. Abel \& Max Rettig, State Statutes Providing for a Right to Counsel in Civil Cases, 40 Clearinghouse Rev. 245 (July-August 2006).

73. New York City adopted a right to counsel in eviction cases in 2017 , with San Francisco and Newark following suit. For a discussion of New York City's initiative, see http://civilrighttocounsel.org/ major_developments/894. For a report on the first year of program's operation, see Universal Access to Legal Services: A Report on Year One of Implementation in New York City, prepared by the Office of Civil Justice, New York City Human Resources Administration at 2 (Fall 2018), available at https://wwwl.nyc.gov/assets/hra/downloads/pdf/services/civiljustice/OCJ-UA-2018-Report.pdf. For an update on the status of efforts in other jurisdictions to secure an equivalent right, including in San Francisco and Newark, see http://www.massrtc.org/national.html.

74. See, http://civilrighttocounsel.org/legislative_developments.

75. Clare Pastore, Life After Lassiter: An Overview of State-Court Rightto-Counsel Decisions, 40 Clearinghouse Rev. 186 (2006). 


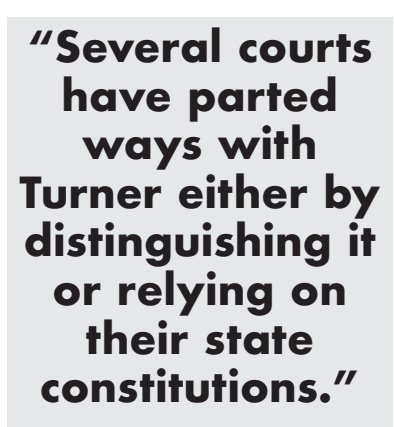

are those from the state appellate courts, including the state supreme courts. Termination of parental rights cases are the largest category of reported right-to-counsel cases; other decisions involve contexts of civil contempt, civil commitment, and paternity. ${ }^{76}$ Where state courts have found a right to counsel, they have sometimes done so through use of the Mathews factors, but concluding that the application under state due process analysis to a particular context compels the finding of a categorical right to counsel. ${ }^{77}$ Other decisions look beyond state due process, exploring theories based on equal protection, the court's "inherent power" or state "pauper" statutes. ${ }^{78}$

The NCCRC also tracks the status of state litigation around the country recognizing a right to counsel in civil contexts. ${ }^{79} \mathrm{Sev}-$ eral courts have parted ways with Turner either by distinguishing it or relying on their state constitutions. 80 Other significant civil right to counsel decisions since 2014 include The Supreme Court of Pennsylvania's decision interpreting its statutory law to require right to counsel for children in termination of parental rights cases, ${ }^{81}$ the Supreme Court of New Jersey's decision recognizing a constitutional due process right to counsel for parents in private adoption cases, 82 and the Massachusetts Supreme Judicial Court's decisions recognizing a state constitutional right to counsel for parents in private guardianship proceedings both when the guardianship is initially established and with petitions to modify or terminate the guardianship. ${ }^{83}$ The Montana Supreme Court held that, under the state constitution's equal protection clause, all parents have a right to counsel in adoption cases. ${ }^{84}$ The Hawaii Supreme Court held that all Hawaii parents have a right to counsel in abuse/neglect and termination of parental rights cases. ${ }^{85}$ The Indiana Supreme Court held that not only do parents have a statutory right to counsel in abuse/neglect cases, but the failure to appoint counsel automatically requires reversal. 86

Judges also make powerful statements through concurring and dissenting opinions in cases where a right to counsel issue is presented and either not reached by the court or rejected by the majority. For example, in Frase v. Barnhart, the Court of Appeals of Maryland invalidated visitation and housing conditions placed on the mother having custody of the child, but declined to reach the issue of whether the mother was entitled to appointment of counsel. 87 In a concurring decision for three judges, including the Chief Judge, Judge Cathell objected to the majority's decision declining to reach the right to counsel issue, noting that "[i]t is, in my view, an important function of this Court to answer questions such as is presented in this case..." as opposed to leaving the question to the political process. ${ }^{88}$ Judge Cathell cited decisions from other states finding a right to counsel in important civil contexts, observed how difficult it must be for poor litigants to navigate the legal system, and noted that the issue, which involves "protection of the family," is fundamental and will not go away, before concluding:

I would reach the ... issue. More important I would resolve it by holding that in cases involving the fundamental right of parents to parent their children, especially when the parent is a defendant and not a plaintiff, counsel should be provided for those parents who lack independent means to retain private counsel. 89

In King v. King, the Washington Supreme Court rejected a case presenting the question as to whether counsel should be appointed for the mother in a private custody dispute where the father was represented by counsel. 90 The court concluded that "fundamental constitutional rights are not implicated in a dissolution proceeding." 91 It concluded further that, in contrast to a termination of parental rights case, the "State's involvement is meaningfully different," since proceeding is between private parties, where "the state neither applies its resources against either party nor instigates the proceeding." 92

In a scathing dissent, Justice Madsen rejected the majority's reasoning, noting that "[civil marriage is an institution that is created, maintained, and controlled by the State to serve state interests" and that the "State controls access to the institution..."93 Moreover, the "fundamental interest at stake in this dissolution proceeding has long been recognized, that is, a parent's fundamental interest in the day-to-day companionship, care and charge of his or her children." Justice Madsen analyzed the gov-
76. Id., at 190.

77. Id., at 197-189.

78. Id., at 193-194.

79. The Coalition's Status Map is available at http://civilrighttocounsel.org/map.

80. See, e.g., Commonwealth v. Diaz, 191 A.3d 850 (Pa. Super. 2018) (right to counsel for those facing incarceration in civil contempt proceeding for inability to pay court fee/fines owed to the government and not a private party); DeWolfe v. Richmond, 76 A.3d 1019, 1029 (Md. 2013) (reaffirming pre-Turner state constitutional case law on right to counsel and stating that "the right attaches in any proceeding that may result in the defendant's incarceration"); State v. Stone, 268 P.3d 226 (Wash. App. 2012) (right to counsel in proceedings to enforce legal financial obligations to the state where incarceration is a possibility).

81. In re Adoption of L.B.M., 161 A. 3d 172 (2017). See http://civilrighttocounsel.org/major_developments/1115.
82. Adoption by J.E.V., 141 A.3d 254 (N.J. 2016). For a discussion of the case, see http://civilrighttocounsel.org/major_developments/ 1016.

83. Guardianship of VV, 470 Mass. 590 (2015); L.B. v. Chief Justice of Probate Court, 474 Mass. 231 (2016). For a discussion of the cases, see http://civilrighttocounsel.org/major_developments/902.

84. In re Adoption of A.W.S. and K.R.S., 2016 MT 194 (2014).

85. In re T.M., 319 P.3d 338 (Hawaii 2014).

86. G.P. v. Indiana Dept. of Child Servs, 4 N.E.3d 1158 (Ind. 2014).

87. Frase, supra note 20.

88. Id., at 133-34.

89. Id., at 142 .

90. King, supra note 20

91. Id., at 664 .

92. Id., at $663,668$.

93. Id., at 672 .

16 Court Review - Volume 56 
erning state court precedent, and explained "the very real effect of what happens when one parent is denied primary residential placement after she has been the primary caregiver of her child."94 Justice Madsen described further the difficulties Ms. King encountered in attempting to navigate the proceeding without the assistance of counsel, and empirical studies showing that "indigent litigants without counsel receive less favorable outcomes than those with counsel," before concluding:

These studies and comments highlight the serious consequences of litigating child placement issues without legal representation. It is a fact of life that a pro se parent cannot navigate the legal channels in a custody dispute with the degree of success that a lawyer can. It is simply unfair to a parent to require her to face a represented opponent in a court of law when her relationship with her children is at stake. 95

\section{iv. Cases Decided by State Judges Involving Non-cate- gorical Rights}

\section{Finding a Right to Counsel on a Case-by-Case Basis}

As the preceding section illustrates, the most widely cited state cases involving whether a categorical right to counsel exists in a certain context are decided by state appellate court judges, and in particular state Supreme Court justices. State trial court judges arguably are best positioned to decide whether counsel must be appointed for a particular litigant in a particular case. Given the volume of cases they handle, state trial court judges should have more frequent opportunities to confront the question. Yet, many, and perhaps most, state trial court judges might be surprised to learn they have not only the authority to appoint counsel, but also an obligation to consider the issue. Despite a presumption against a right to counsel in Lassiter and Turner, those decisions did not hold that there is no federal constitutional right to counsel in these settings. Rather, Lassiter states that a litigant may overcome that presumption on a case-by-case basis by demonstrating that the Mathews factors favor appointment of counsel. Nothing in Turner undercuts this portion of Lassiter.

Despite the governing doctrine and the enormous number of pro se litigants, there is no evidence that judges follow the holdings of Lassiter and Turner and actually analyze whether individual cases require appointment of counsel. As Clare Pastore observes "[d]etermining how, and how often, the trial courts actually perform this due process analysis is a remarkably difficult task

"96 Busy judges may not recognize litigants' assertions that they are ill-equipped to handle their cases without a lawyer, or frustrations with their inability to obtain counsel, as raising a question as to whether counsel should be appointed. The reality may flow from the high volume of unrepresented litigants flooding the courts, the crowded dockets of judges in the state courts, and the absence of a dedicated funding stream to pay for counsel on a case-by-case basis. The result is that, while the governing doctrine on its face requires judges to per-

"[T]hey [state
trial court
judges] have not
only the
authority to
appoint counsel,
but an obligation
to consider the
issue."
form the requisite analysis when facts suggest that an unrepresented litigant might be deprived of due process, it is the exception, rather than the norm, when a judge actually does so.

The Alaska Superior Court case of Gordanier v. Jonsson is one noteworthy example of a trial court working through the constitutional analysis and concluding that counsel must be provided for a particular litigant in a civil setting. ${ }^{97}$ The case involved a custody dispute, where Mr. Gordanier had retained private counsel. Ms. Jonsson was forced to represent herself, having twice had her case rejected by the local legal services office, and being unable to secure counsel from any other source. The Court found that Ms. Jonsson could not afford counsel, that no statute provided a basis for appointment of counsel, and that the fact that there might be pro bono services available did not relieve the court of its obligation to perform the requisite constitutional analysis. 98 The Court worked through the guiding Alaska Supreme Court decisions on state due process, which included analysis of the Mathews factors, concluding that state due process required appointment of counsel. 99 The Court found additional authority under state and federal equal protection provisions. 100

A decade later, a Massachusetts Housing Court judge followed Lassiter and Turner in concluding, based on the particular facts of the case before her, that the tenant should be appointed counsel in an eviction proceeding tied to a related criminal prosecution. ${ }^{101}$ The Court recognized the untenable position the unrepresented tenant faced, being forced to choose between defending against the summary eviction proceeding and waiving his privilege against self-incrimination in the process, or preserving his privilege but thereby being unable to present a defense in the eviction proceeding. The Court found its authority both from the due process analysis and from "sound administrative of justice principles," which required appointment. The Court's due process analysis involved a straight application of Lassiter and Turner, first acknowledging that while there "is no automatic right to counsel in civil proceedings," the question of whether due process requires appointment of counsel is "to be answered

\section{Id}

95. Id., at 679-80

96. See Pastore, supra note 75, at 186. "Without a detailed analysis of trial court minute orders, records, and perhaps even transcripts, how often pro se litigants request counsel, much less how courts handle such requests in the vast bulk of unappealed cases, is impossible to tell." Id.

97. Gordanier v. Jonsson, No. 3AN-06-8887 CI (Alaska Sup. Ct. Aug. 14, 2007), available at http://civilrighttocounsel.org/news/recent_ developments/16/. The case became moot before resolution by the
Alaska Supreme Court.

98. Id., at 4-5.

99. Id., at 5-11.

100. Id., at 11-15

101. Worthy Apartments v. Kremer, No. 16-SP-3216, Rulings and Order on Appointment of Counsel and Motion to Extend Stay (December 8, 2017) (Housing Court Department, Western Division) (decision available at http://civilrighttocounsel.org/major_ developments/1288). 


"'[T]he
inequality in
representation
deprives
tenants of their
legal rights...'"

in the first instance by the trial court, subject, of course, to appellate review."102

In this case, the tenant's significant private interest in his subsidized housing, combined with the risk of self-incrimination in the related criminal case, and in light of the tenant's disability and demonstrated difficulty navigating the complexity of conducting a trial without counsel, combine to persuade the court that nothing short of appointing counsel suffices to protect the tenant's rights under the federal and state constitutions. 103

The Court further noted that no "substitute procedural safeguards" as envisioned by Turner would allow the tenant to defend himself effectively. "Rather, any defense in this case requires an understanding of complex legal issues, and the expert skills needed to apply that understanding to the facts and the evidence offered." 104

\section{Acknowledging Context}

Even when cases do not directly raise the question of whether counsel should be appointed, judges may be presented with opportunities to write decisions that reveal the challenges unrepresented litigants may face obtaining meaningful access to justice. These decisions can shape the direction of access to justice and civil right to counsel jurisprudence. For example, twentyfive years before the right to universal access to counsel in eviction cases in New York City became a reality, Civil Court Judge Marcy S. Friedman was faced with motion to set aside a settlement agreement in 144 Woodruff Corp. v. Lacrete. ${ }^{105}$ The agreement was reached between a represented landlord and an unrepresented tenant in which the tenant had agreed to pay a monthly rental amount over two times greater than the legal regulated rent for her rent-stabilized apartment. ${ }^{106}$ The decision is remarkable not only for the holding, but for the extensive context Judge Friedman provides. She first reviews the governing New York case law under which a court-approved stipulation may be set aside where a party has been without counsel, demonstrating that the good cause standard extends to situations where a stipulation is unduly harsh or unjust and the parties may be returned to their prior status. 107 As Judge Friedman illustrates, the application of the governing standards to the facts of the case warrants setting aside the agreement. ${ }^{108}$

The decision could have ended there. Instead, Judge Friedman writes at length about the plight of unrepresented tenants in Housing Court and how the issue "has become the subject of increasing concern and consideration by the chief administrators of the courts and distinguished committees of the bar."109 Judge Friedman discusses many of the studies that have connected the lack of representation to "increasing concern and led one Commission to call for mandatory pro bono." She quotes a different study concluding that "the inequality in representation deprives tenants of their legal rights... and that the 'provision of counsel to persons facing eviction constitutes the single indispensable reform required in the Housing Court." 110 The Court cites from these reports at length before showing how the facts of the case before her fit squarely into the scenarios identified by the Committees and Commissions. After demonstrating the untenable position faced by Housing Court judges asked to approve agreements between represented landlords and unrepresented tenants, the Court observes that the "critical problems caused by lack of representation for tenants in Housing Court can only be addressed from a number of perspectives." Judge Friedman discusses different fixes, noting that:" $[\mathrm{g}]$ reater availability of counsel is the obvious but crucial long-term solution."111

In 2019, the Massachusetts Supreme Judicial Court followed a similar path in Adjartey v. Central Division of the Housing Court Department. ${ }^{112}$ Adjartey involved an appeal from pro se litigants alleging bias in certain aspects of the operation of the Central Housing Court in Worcester. Although the Court did not ultimately grant the appellants the relief they requested, the Court, in a decision authored by Chief Justice Gants, issued a 35-page decision, with a 25-page Appendix, explaining the challenges unrepresented litigants face in summary process eviction cases in Massachusetts courts. Under a heading labeled "The complexity and speed of summary process cases, and the disparities in legal representation between landlords and tenants," the court addresses the broader context: "the unique nature of a summary process eviction." The Court notes that "summary process cases are complex, fast-moving and generally litigated by landlords who are represented by attorneys and tenants who are not." 113 After discussing the nature of summary process cases, and the data showing the disparity in representation between landlords and tenants, the Court observes: "[t]he result, in most cases, is that the landlord has an attorney who understands how to navigate the eviction process and the tenant does not." 114 The court notes further that legal services organizations are severely under-resourced, and the wealth of information online is an inadequate substitute for representation. The court adds that the assistance of nonlawyers may be the only option "[i]n a complex, high-stakes process where the right to counsel is not guaranteed and professional assistance is not universally available." 115

The decisions in Adjartey and 144 Woodruff Corp. v. Lacrete used cases that did not present a right to counsel issue to illus-
102. Id., at 1 .

103. Id., at 2 .

104. Id. Kremer involved an unusual procedural process. The Court initially used its powers to appoint the lawyer as a guardian ad litem, but then kept the lawyer in place to litigate the case. Id.

105. 585 N.Y.S.2d 956 (1992).

106. Id.

107. Id., at 957-958.
108. Id., at 958.

109. Id.

110. Id. (emphasis in original).

111. Id., at 959.

112. 481 Mass. 830 (2019).

113. Id., at 834 .

114. Id., at 838 .

115. Id., at 840 .

18 Court Review - Volume 56 
trate how counsel is essential in a particular context. The decisions echo and support legislative initiatives that seek to address the problems faced by the courts where parties are forced to appear without counsel. For example, the legislative findings that helped support California legislation that established the Sargent Shriver Civil Counsel Act ${ }^{116}$ include:

Many judicial leaders acknowledge that the disparity in outcomes is so great that indigent parties who lack representation regularly lose cases that they would win if they had counsel. ${ }^{117}$

In some cases, justice is not achievable if one side is unrepresented because the parties cannot afford the cost of representation. The guarantees of due process and equal protection as well as the common law that serves as the rule of decision in California courts underscore the need to provide legal representation in critical civil matters when parties cannot afford the cost of retaining a lawyer. ${ }^{118}$

\section{A. THE BULLY PULPIT}

\section{i. Articles, Speeches and Amicus Briefs}

The potential role for judges to help identify the context where a civil right to counsel is necessary extends far beyond the cases they decide. Judges have been in the forefront of the efforts to shape our understanding of the need for a civil right to counsel through their writings. Judge Robert Sweet played an important role in restarting the conversation about the need for a civil Gideon with his published writings toward the end of the 1990s. 119 Justice Earl Johnson pressed the case for a civil right to counsel both through his writings 120 and his judicial opinions ${ }^{121}$ while on the California Court of Appeal building on ideas he promulgated before joining the bench. ${ }^{122}$ Judges Denise Johnson, ${ }^{123}$ Lora Livingston, ${ }^{124}$ Jon Levy, ${ }^{125}$ Mark Juhas, ${ }^{126}$ David Dreyer ${ }^{127}$ and Ron Spears ${ }^{128}$ are among others who have helped make the case for a civil right to counsel in law review articles, bar journals, and other writings in recent years

Whether by using the bully pulpit, appointing task forces, or using other tools, state Chief Justices can play a crucial role in providing momentum and leadership for an expanded civil right to counsel. Chief Judge Jonathan Lippmann of New York played a crucial role in the initiatives that led New York City to become
116. See Assembly Bill 590 (2009), available at http://leginfo.legislature.ca.gov/faces/billTextClient.xhtml?bill_id=200920100AB590 \&search_keywords=shriver. See also Note, California Establishes Pilot Programs to Expand Access to Counsel for Low-Income Parties, 123 Harv. L. Rev. 1532 (2010). "Many Californians are unable to meaningfully access the courts and obtain justice in a timely and effective manner. The effect is that critical legal decisions are made without the court having the necessary information, or without the parties having an adequate understanding of the orders to which they are subject." Id., $\$ 1(b)$.

117. Id., \$1(g). "A growing body of empirical research confirms the widespread perception that parties who attempt to represent themselves are likely to lose, regardless of the merits of their case, particularly when the opposing party has a lawyer, while parties represented by counsel are far more likely to prevail." Id.

118. Id., $\S 1(\mathrm{k})$. The findings note further that "[t]he adversarial system of justice relied upon in the United States inevitably allocates to the parties the primary responsibility for discovering the relevant evidence, finding the relevant legal principles, and presenting them to a neutral judge or jury. Discharging these responsibilities generally requires the knowledge and skills of a legally trained professional. The absence of representation not only disadvantages parties, it has a negative effect on the functioning of the judicial system." Id., §1(i).

119. Robert W. Sweet, Civil Gideon and Confidence in a Just Society, 17 Yale L. \& Pol'y Rev. 503 (1998); Robert W. Sweet, Civil Gideon and Justice in the Trial Court (the Rabbi's Beard), 52 RECORD OF THE Ass'N OF THE BAR OF THE City OF N.Y. 915 (1997).

120. See, e.g., Johnson, Will Gideon's Trumpet Sound A New Melody?, supra note 52; Johnson, Three Phases, supra note 18

121. See, Quail v. Municipal Court, 171 Cal.App.3d 572 (1987) (Johnson, J., concurring in part and dissenting in part), Justice Johnson dissented from the portion of the court decision upholding the denial of the request for appointed counsel, both on appeal and at the trial court level, identifying various grounds for recognizing a right to counsel in civil cases, including due process, equal protec- tion, incorporation of English common law that had recognized such a right, and the court's inherent authority.

122. Earl Johnson, Jr., Thrown to the Lions: A Plea for a Constitutional Right to Counsel for Low-Income Civil Litigants, B. LEADER MAG., Sept.-Oct. 1976; Earl Johnson, Jr. \& Elizabeth Schwartz, Beyond Payne: The Case for a Legally Enforceable Right to Representation in Civil Cases for Indigent California Litigants, 11 Loy. L.A. L. REv. 249 (1978). Justice Johnson reflected on his extensive involvement in the right-to-counsel movement in his 2013 article published in Clearinghouse Review. Earl Johnson Jr., 50 Years of Gideon, 47 Years Working Toward a "Civil Gideon," 47 Clearinghouse Rev., May-June 2013, at 35.

123. Denise Johnson, Bridging the Gap, App. J. News 11 (2006). Justice Johnson was an Associate Justice of the Vermont Supreme Court at the time her article was published.

124. Laura Abel and Judge Lora Livingston, The Existing Civil Right to Counsel Infrastructure, Judges' J., Fall 2008, at 24. Justice Livingston was the Presiding Justice of the 261st District Court in Texas when she co-authored this piece.

125. Hon. Jon Levy, The World Is Round: Why We Must Assure Equal Access to Civil Justice, 62 Me. L. Rev. 561 (2010). Justice Levy was an Associate Justice of the Maine Supreme Court when he published this article, and later was appointed to the United States District Court in Maine.

126. Mark Juhas, On the Anniversary of Gideon, an Argument for Free Civil Representation, L.A. Law., Sept. 2013, at 44. Judge Juhas serves as a judge of the California Superior Court, County of Los Angeles.

127. Hon. David J. Dreyer, Deja Vu All Over Again: Turner v. Rogers and the Civil Right to Counsel, 61 Drake L. Rev. 639, 651 (2013). Judge Dreyer is a judge of the Marion County Superior Court in Indiana.

128. Hon. Ron Spears, An Adversary System Without Advocates, 101 Ill. B.J. 592 (Nov. 2013). Judge Spears was a resident judge of the Fourth Circuit in Christian County, Illinois at the time the article was published. 


"[U]nrepre-
sented civil
litigants
represent a
significant and
growing burden
on the judicial
system
caseloads."

the first jurisdiction to adopt a right to counsel for tenants facing eviction. Judge Lippmann used law review articles and speeches ${ }^{129}$ to help make the case for the right to counsel, while appointing task forces that explored the issues and helped demonstrate the need.130 Judge Lippmann continued to press the cause after his retirement in 2015, becoming an important voice in the successful New York City initiative. 131 Other Chief Justices, including Chief Justice Broderick of New Hampshire, ${ }^{132}$ Chief Justice Gants of Massachusetts, 133 Chief Justice George of California, ${ }^{134}$ Chief Justice Chase Rogers of Connecticut, 135 and Jess Parker, Presiding Judge of the Supreme Court of Mississippi, 136 have raised the importance of the need for representation to level the playing field in their state courts.
Judges have seized other opportunities to present their unique perspective on issues relating to unrepresented litigants, the challenges they face in achieving fairness in the courts, and the need for counsel. For example, eleven sitting and retired judges from the Milwaukee and Dane County Circuit Courts in Wisconsin filed an amicus brief in Kelly v. Warpinski. ${ }^{137}$ In Kelly, petitioners asked the Wisconsin Supreme Court to take original jurisdiction and rule on their argument that the state constitution conferred a right to appointed counsel in civil cases. Without taking a position on the appropriate remedy, the judges drew from their experience and explained how unrepresented civil litigants represent a significant and growing burden on the judicial system, which is not well-equipped to deal with them. They discussed how "pro se litigants" are a significant and growing part of state trial courts' caseloads, how unsophisticated and inexperienced pro se litigants complicate the process, and how the inherent power of the trial courts to appoint counsel has not been an effective means of addressing the problem. 138 Sixteen retired judges in Washington State similarly filed an amicus brief in the Washington State
129. See, e.g., Chief Judge Jonathan Lippmann, New York's Template to Address the Crisis in Civil Legal Services, 7 Harv. L. \& Pol'y Rev. 13, 27-29 (2013); "Justice, Justice Shall You Pursue:" The Chief Judge's Perspective on Justice and Jewish Values, speech to the Central Synagogue of New York (Feb. 5, 2010) on file with author; Judge Jonathan Lippmann, Essay: Shifting the Landscape on Access to Justice, 38 Cardozo L. Rev. 1159 (Feb. 2017); Remarks of Chief Judge Jonathan Lippmann (ret.), Shifting the Landscape on Access to Justice, pp. 14-15, Keynote Speaker, 2016 Hawaii Access to Justice Conference (June 24, 2016), available at http://25shu2g61cw30sjn46t4k87by.wpengine.netdnacdn.com/wp-content/uploads/2016/02/chief-judge-lippmansremarks.pdf.

130. See, e.g., Report to the Chief Judge of the State of New York, 1518 (Nov. 2010), available at http://ww2.nycourts.gov/ sites/default/files/document/files/2018-04/CLS-TaskForceREPORT.pdf; Report to the Chief Judge of the State of New York, 1921 (Nov. 2011), available at http://ww2.nycourts.gov/sites/ default/files/document/files/2018-04/CLS-2011TaskForceREPORT_web.pdf; Report to the Chief Judge of the State of New York, 15-16 (Nov. 2012), available at http://ww2.nycourts. gov/sites/default/files/document/files/2018-04/CLS-TaskForceREPORT_Nov-2012.pdf.

131. See, e.g., History of the Right to Counsel NYC Coalition, available at https://d3n8a8pro7vhmx.cloudfront.net/righttocounselnyc/ pages/10/attachments/original/1517948094/history_of_RTC.pdf? 1517948094

132. In remarks to the National Access to Justice Conference in Minneapolis, Minnesota in 2008, Chief Justice Broderick described having appointed a Citizens Commission to examine the New Hampshire State Courts, which recommended that New Hampshire "examine the expansion of legal representation to civil litigants unable to afford counsel and study the implementation of a civil Gideon" for the poor threatened with the loss of shelter, safety, sustenance, health, and custody of a child (speech on file with author).

133. Among other initiatives, Chief Justice Gants led a project management team that developed the Massachusetts Justice for All Strategic Action Plan, which in part calls for Massachusetts to consider following the lead of New York City in instituting a right to counsel for tenants in most eviction cases and providing the funding necessary to implement that right." See http://www.massa2j.org/a2j/wp-
content/uploads/2018/01/Massachusetts-JFA-Strategic-ActionPlan.pdf(hereinafter "MA SAP"). In his 2019 State of the Judiciary speech, Chief Justice Gants referred to the "legislative efforts afoot here in Massachusetts to provide legal counsel for all indigent parties in eviction proceedings" and stated, "I hope that by next year these efforts may finally come to fruition." See https://www.mass.gov/news/supreme-judicial-court-chief-justiceralph-d-gants-delivers-state-of-the-judiciary-speech-2019.

134. The report to the ABA House of Delegates in support of ABA Resolution 112a, at 10, quoted Chief Justice Ronald George's State of the Judiciary Speech to the California Legislature, 2001: "[E]very day the administration of justice is threatened . . by the erosion of public confidence caused by the lack of access." See https://www.americanbar.org/content/dam/aba/administrative/lega 1_aid_indigent_defendants/ls_sclaid_resolution_06a112a.pdf.

135. At a meeting of the Connecticut Bar Association, Justice Rogers stated that a civil right to counsel is an issue "we need to confront," and added that "it's time for Connecticut to accelerate serious and comprehensive discussions regarding representation for people who cannot afford counsel in certain types of cases. I say this in full recognition of the financial limitations that exist in contemplating civil Gideon, but also in the hope that a dialogue with the bar as a very active participant will lead to further enhancement of access to justice." See, http://civilrighttocounsel.org/major_developments/939. The first recommendation of the resulting task force was that the legislature should "establish a statutory civil right to counsel in three crucial areas where the fiscal and social cost of likely injustice significantly outweighs the fiscal cost of civil counsel." See, Report of the Task Force to Improve Access to Legal Counsel in Civil Matters, at 4 (2016) (report available at http://www.rc.com/upload/O-Hanlan-Final-Report-of-CT-LegTask-Force-12_2016.pdf).

136. See, Jess H. Dickinson, A Look at Civil Gideon: Is There a Constitutional Right to Counsel in Certain Civil Cases?, 37 U. ARK. LitTLE Rock L. REV. 543 (2015).

137. Kelly, supra note 20.

138. Portions of the amicus brief are reprinted in the July-August Symposium Issue of Clearinghouse Review dedicated to the topic of a civil right to counsel. Judges' Views of Pro Se Litigants' Effect on Courts, 40 Clearinghouse Rev. 163 (2006). 
Supreme Court in support of a right to counsel in contested custody matters in King. ${ }^{139}$

\section{ii. Commissions and Committees}

Nor are the views of judges by any means limited to the context of litigation. The resolutions of the Conference of Chief Justices include important calls for reform of state court proceedings to lower barriers to access. The landmark Resolution 5 (2015) reaffirms the Commitment to Meaningful Access to Justice for All. ${ }^{140}$ Judicial responses to survey questions may also bolster the case for a right to counsel. For example, a survey of Massachusetts judges revealed that lack of representation slows procedures, forces repeat appearances and filings, and causes an increase in court staff time in assisting unrepresented litigants. ${ }^{141}$ Sixty-one percent of the judges responding to the survey reported that the lack of representation "negatively impacts the court's ability to ensure equal justice to unrepresented litigants." 142

Using the broader lens of access to justice, which often intersects with and supports right to counsel efforts, individual judges play important roles in the state access to justice commissions. Some Commissions have endorsed the concept of a right to counsel in certain civil contexts, while others have studied the right to counsel as part of their work. ${ }^{143}$ The Commissions usually are created by order of a state's highest court and typically include a number of judges from throughout the court system among their members. ${ }^{144}$ Many commission chairs or co-chairs are sitting or retired judges. ${ }^{145}$

Judges have served on, and often chaired, other committees and entities that have called for the implementation of a right to counsel or studied the challenges for unrepresented litigants in court exposing, at a minimum, the need for systemic change to remove barriers to meaningful access. Justice Howard H. Dana, Jr. of the Maine Supreme Court chaired the ABA Task Force on Access to Civil Justice that produced the landmark ABA Resolution calling for a civil right to counsel where basic human needs are at stake. ${ }^{146}$ The reports to the Connecticut Supreme Court and to Chief Judge Lippmann in New York that described the barriers to meaningful access and supported the call for a right to counsel in certain civil contexts are among the many examples. ${ }^{147}$

\section{CONNECTING A CIVIL RIGHT TO COUNSEL AND ACCESS TO JUSTICE}

Before concluding an article focused on the judge's role in civil right to counsel initiatives, it is important to connect a civil right to counsel to broader access to justice issues. Some literature suggests a tension between the ideas, recognizing that in certain contexts, access to justice initiatives short of a right to counsel might lead to second-class justice. ${ }^{148}$ Some critics of a civil right to counsel point to problems with the criminal justice system,
139. King, supra note 20. The brief of the retired judges is available on the website of the National Coalition for a Civil Right to Counsel at http://civilrighttocounsel.org/uploaded_files/36/Amicus_brief_ of_retired_judges.pdf.

140. Resolution 5, supra note 1.

141. Investing in Justice, supra note 44.

142. Id., at 61 . When judges speak as a group, the message can be powerful. Although unrelated to the issues of right to counsel and unrepresented litigants, retired judges recently formed an ad hoc Committee for Judicial Independence in response to the federal indictment of Judge Shelley M. Richmond Joseph regarding her involvement in a criminal case with a defendant sought by ICE (United States Immigrations and Customs Enforcement) agents. Seventy-eight retired judges signed a declaration condemning the indictment. See https://masslawyersweekly.com/2019/05/14/coalition-of-retired-judges-speak-out-against-joseph-indictment/. Sixty-one judges signed on to an amicus brief filed in federal court and urging dismissal of the obstruction charges. See https://masslawyersweekly.com/2019/09/16/retired-judges-dismiss-chargesagainst-judge-shelley-joseph/?utm_term=Retired $\% 20$ judges $\%$ 3A\%20dismiss\%20charges\%20against\%20Judge\%20Shelley\%20J oseph\&utm_campaign=Voiding\%20of\%20guilty\%20verdict $\% 201$ atest $\% 20$ twist $\% 20$ in $\% 20$ federal\%20conspiracy\%20case\&utm_co ntent $=$ email\&utm_source $=$ Act $-O n+$ Software\&utm_medium $=$ email.

143. "The Access to Justice Commissions in Arkansas, Maryland, Massachusetts, North Carolina, and Wisconsin have endorsed the concept of a right to counsel in basic human needs civil cases, while the commissions in California, Hawaii, New Hampshire, New
Mexico, South Carolina, and Texas have studied civil right to counsel at one time or another." See http://civilrighttocounsel.org/ about/what_do_judges_think.

144. See, State Access to Justice Commissions: Creation, Composition, and Further Details Prepared by the ABA Resource Center for Access to Justice Initiatives (March/April 2018), available at https://www.americanbar.org/content/dam/aba/administrative/lega l_aid_indigent_defendants/ATJReports/ls_sclaid_atj_commissions_structure.pdf.

145. Id

146. See https://www.americanbar.org/content/dam/aba/administrative/legal_aid_indigent_defendants/ls_sclaid_06A112A.authcheck dam.pdf.

147. See, e.g., nn. 129-31, 135, supra.

148. See, e.g., Richard Zorza, The Relationship of the Right to Counsel and Self-Represented Litigant Movements, MGMt. InFo. ExCHANGE J., 47, 49 (Summer 2012) ("Right to counsel advocates are much more skeptical of the practical ability of self-represented litigants to obtain fair outcomes"); Steinberg, supra note 41, at 457, 505 (2011) (reporting on findings from an empirical study that "support a hypothesis that the unbundled services model might not provide benefits to all assisted clients in all circumstances, as has been presumed) ("Unbundling should promote equal justice and not just equal access"); John Pollock and Michael Greco, It's Not Triage if the Patient Bleeds Out, 161 U. PA. L. Rev. OnLine 40, 48 (2012) ("[A]ll solutions, not just the right to counsel, ought to be studied to determine their effectiveness; if pro se assistance is ineffective in a given situation, it is not the right solution merely because it costs less"). 


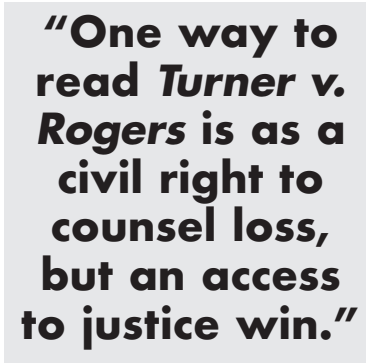

including inadequate funding, high caseloads, and the prevalence of ineffective assistance of counsel, as reasons to question whether a civil right to counsel is even a desirable goal. ${ }^{149}$ One way to read Turner $v$. Rogers is as a civil right to counsel loss, but an access to justice win. ${ }^{150}$

Rather than viewing the concepts of access to justice and civil right to counsel as in conflict, it is more appropriate and constructive to recognize the approaches as connected. A civil right to counsel in certain scenarios becomes as a key component of an overarching access to justice strategy. This approach gives meaning to Resolution 5's goal of achieving " 100 percent access to effective assistance for essential civil legal needs ... through a continuum of meaningful and appropriate services." 151 The concepts of a continuum of services and service pyramids are among the vehicles that those working on access to justice issues use to help match the universe of resources to assist those with legal problems. ${ }^{152}$

My preferred formulation, articulated elsewhere, is to synthesize these ideas in a three-pronged access to justice strategy:

(1) changes in the operation of the forum, including the expansion of the roles of the court system's key players, such as judges, court-connected mediators, and clerks, to require them to assist unrepresented litigants as necessary to prevent a forfeiture of important rights;
(2) the use of assistance programs, rigorously evaluated to identify which most effectively protect litigants from the forfeiture of rights; and

(3) the adoption of a civil right to counsel where the expansion of the roles of the key players and the assistance programs do not provide the necessary help to vulnerable litigants. 153

The three-pronged approach serves as a reminder that each of the three areas of focus must be utilized as part of the solutions to access to justice problems. Since Prong 1 focuses on the forum, judges necessarily play a vital role. How judges manage their courtrooms and handle cases involving self-represented litigants is a crucial factor in how successfully the courts provide meaningful access to justice. As the analysis of Lassiter and Turner above reveals, this includes having judges recognize the scenarios in which they must perform the analysis to determine whether due process and meaningful access require appointment of counsel in a particular case before them.

A great deal of scholarly attention has focused on judicial ethics and the tools judges need to be active and engaged while remaining neutral. ${ }^{154}$ The past fifteen years have seen the development of training materials and guidance designed to help judges navigate these tricky scenarios. ${ }^{155}$ Increased acceptance of the idea that neutrality does not mean passivity has led to modifications to key provisions of the Model Code of Judicial Ethics and equivalent provisions in many states. 156 The need is para-
149. See, e.g., Benjamin H. Barton, Against Civil Gideon (and for Pro Se Court Reform), 62 FLA. L. REV. 1227 (2010).

150. See, e.g., Russell Engler, Turner v. Rogers and the Essential Role of the Courts in Delivering Access to Justice, 7 Harv. L. \& Pol'y Rev 31, 31 (2013). A blog symposium in the aftermath of the Turner decision suggested a variety of interpretations as to the decision's meaning and potential impact. See, Symposium (Turner $v$. Rogers), CONCURRing Opinions, available at https://bit.ly/38xOC6o. Richard Zorza, an expert in self-represented litigation, and David Udell, the Director of the National Center for Access to Justice, moderated the discussion. Some have argued that the civil-right-to-counsel movement successfully shifted to state constitutions long before Turner was decided. See, e.g., John Pollock, Turner v. Rogers: Why the Supreme Court Is a Day Late and a Dollar Short, CONCURRING Opinions (2011), available at https://bit.ly/38xOC6o.

151. See Resolution 5, supra, note 1; MA SAP, supra note 133.

152. See, e.g., MA SAP, supra note 133, at 17-18

153. See, e.g., Russell Engler, Towards a Context-Based Civil Gideon Through Access to Justice Initiatives, 40 Clearinghouse Review 196 (July-August 2006). For an explanation of the three prongs, see, id., at 42-43. I have also explored how the pieces of the comprehensive strategy are in place and tremendous activity is occurring, primarily at the state level, with activities at each of the three prongs. Engler, supra note 150, at 45-50.

154. See, e.g., Russell Engler, Ethics in Transition: Unrepresented Litigants and the Changing Judicial Role, 22 Notre DAME J. L. Ethics \& PuB. Pol'Y 367 (2008); Richard Zorza, The Disconnect Between the Requirements of Judicial Neutrality and Those of the Appearance of Neutrality when Parties Appear Pro Se: Causes, Solutions, Recommendations, and Implications, 17 Geo. J. Legal Ethics 423 , 423 (2004).
155. See, e.g., Cynthia Gray, Reaching Out or Overreaching: Judicial Ethics And Self-RePresented Litigants (2005), available at https://www.ncsc.org/ /media/Files/PDF/Topics/Center\%20for\%2 OJudicial\%20Ethics/Publications/Judicial-Ethics-and-Self-Represented-Litigants.ashx. Since October 1990, Cynthia Gray has been Director of the Center for Judicial Ethics, now part of the National Center for State Courts (NCSC), a national clearinghouse for information about judicial ethics and discipline; she summarizes recent cases and advisory opinions, answers requests for information about judicial conduct, and writes a weekly blog (at www.ncscjudicialethicsblog.org). Curricula relating to "Access to Justice for the Self-Represented Litigant," developed jointly by the Self-Represented Litigants Network (SRLN) and the NCSC, are available at https://www.srln.org/node/202/judicial-curricula-access-justiceself-represented.

156. To address the scenario involving self-represented litigants, the Model Code was amended to add Comment [4] to Rule 2.2, relating to Impartiality and Fairness: "It is not a violation of this Rule for a judge to make reasonable accommodations to ensure pro se litigants the opportunity to have their matters fairly heard." See, https://www.americanbar.org/groups/professional_responsibility/p ublications/model_code_of_judicial_conduct/model_code_of_jud icial_conduct_canon_2/rule2_2impartialityandfairness/commentonrule2_2/. Resolution 2 (2012) of CCJ and COSCA recommended that states adopt modifications to Rule 2.2 and the relevant comments to provide for flexibility for judges in these scenarios. Resolution 2: In Support of Expanding Rule 2.2 of the ABA Model Code of Judicial Conduct to Reference Cases Involving Self-Represented Litigants (2012), available at https://ccj.ncsc.org/ /media/Microsites/Files/CCJ/Resolutions/07252012-Support- 
mount for greater research and information aimed at increasing our understanding of the roles of state judges in civil cases where a large number of litigants are unrepresented by counsel. ${ }^{157}$

Nor is the need for judicial leadership to expand access to justice limited to the courtroom. Components of access to justice initiatives that fit squarely in Prong 1, involving the operation of the forum, include:

- moves toward simplification, including with revised pleadings and forms;

- increased use of technology in the courthouse;

- the advent of self-help centers, pro se clerks, and facilitators; and

- the focus on clerks and court-connected mediators.

The Strategic Plan for the Trial Courts in Massachusetts has included a high-level strategy involving Access to Justice and User Experience. The tactics to implement the strategy include simplifying and standardizing court forms and accompanying self-help materials, ensuring that all court users have equal access to all court programs, an expansion of interactive self-help assistance by court personnel, and expanded interactive self-help assistance by court staff. ${ }^{158}$ Judges play a crucial role in pushing for, and helping to implement, these changes.

Although Prong 1 suggests a focus on the courts, administrative agencies cannot be ignored as fora in which important rights of many people are adjudicated, but where they often appear without counsel. Moreover, access to justice initiatives increasingly add an "upstream" focus to try to identify and resolve legal problems in advance of court. ${ }^{159}$ Finally, whether initiatives at Prongs 1 and 2 will be sufficient to provide meaningful access should be informed by reliable empirical work. ${ }^{160}$

Judges also provide crucial leadership and understanding at Prong 2, involving assistance programs. Successful lawyer for the day programs require judicial support. For example, the prolifer- ation of these programs in Massachusetts followed the recommendation of a Supreme Judicial Court Steering Committing on Self-Represented Litigants, whereas only a decade before, efforts to create lawyer-for-the-day programs in the Massachusetts Housing Court met stiff resistance from the Court's
"Judges play a crucial role in pushing for, and helping to implement, these changes."
Chief Justice. 161 Where jurisdictions have approved "unbundled legal services" or expanded roles for lay advocates in proceedings, judicial resistance has provided a crucial impediment, and while judicial support has led to the implementation of successful programs. ${ }^{162}$

Prong 3, involving representation by lawyers, including a right to counsel where necessary to provide meaningful access to justice, has been the focus this article. Initiatives at Prong 3 also embrace efforts to expand funding for legal aid and increase pro bono participation among lawyers, initiatives in which judges often play crucial roles. ${ }^{163}$ Consistent with an overall access to justice strategy, the three-pronged analysis underscores the fact that a civil right to counsel has never meant a goal of providing, at public expense, lawyers for all litigants in all civil cases. ${ }^{164}$ Rather, the analysis recognizes the imperative of creating a right to counsel where basic human needs are at stake in the proceedings, but embraces a full range of access to justice initiatives for the overall operation of the courts and administrative agencies.

\section{CONCLUSION}

One goal of this article has been to describe the range of actions that many judges have undertaken to help move forward important initiatives designed to provide meaningful access to justice and equal justice under the law. Individual judges will have different levels of comfort or interest in stepping into the various roles described in this article. Yet, in contexts in which
Expanding-Rule-ABA-Model-Code-Judicial-Conduct-Self-Representing-Litigants.ashx. For a discussion of the early states adopting the modifications to Rule 2.2 or comparable language, see Russell Engler, The Toughest Nut: Handling Cases Pitting Unrepresented Litigants Against Represented Ones, 62 Juv. \& FAM. Cт. J. 10, 13 (2011).

157. See, e.g., Anna E. Carpenter, Jessica K. Steinberg, Colleen F. Shanahan \& Alyx Mark, Studying the "New" Civil Judges, 2018 Wis. L.J. 249 (2018).

158. Massachusetts Trial Court, Strategic Plan 2.1, 27-29, available at https://www.mass.gov/files/documents/2019/04/10/sp2.1.pdf (Strategic Plan 2.0 was issued in October 2016. Strategic Plan 2.1 added a Diversity, Equity and Inclusion Domain in April 2018). Id.

159. See, e.g., MA SAP, supra note 133, at 39-43, 62-66.

160. See, supra, nn. 39-43 and accompanying text.

161. See Addressing the Needs of Self-Represented Litigants in Our Courts: Final Report and Recommendations (November 21, 2008) (available at https://www.mass.gov/files/documents/2016/08/mr/ self-rep-final-report.pdf.) For a description of the battle to create Lawyer for the Day programs in the Housing Courts, see Russell Engler, And Justice for All-Including the Unrepresented Poor: Revisiting the Role of Judges, Mediators, and Clerks, 67 FORDHAM L. REv. 1987, 2062-63 (1999).
162. See, e.g., Steinberg, supra note 41, at 455-56, 465-70.

163. See generally, Part III.B., supra. Many of the Commissions and Committees discussed in that section involve not only the issue of a civil right to counsel, but more generally the need for an expansion of legal services and increased use of pro bono attorneys, among other responses to the access to justice challenges.

164. This is one of the reasons that many proponents of an expanded civil right to counsel avoid the term "civil Gideon."

Part of that nomenclature preference relates to the problems with the implementation of Gideon: It is our hope, and our mission, to ensure that new rights to counsel are accompanied by sufficient funding in order to avoid the nightmare caseload scenario that has plagued indigent defense. But also, the scope of the right we pursue is markedly different. For one, Gideon ensures a right to counsel for all indigent criminal defendants (provided they face jail time), whereas our movement focuses only on cases implicating basic human needs.

John Pollock, It's All About Justice: Gideon and the Right to Counsel in Civil Cases, 27 MIE J. 5, 6 (Winter 2013). 
nothing short of representation by a lawyer can achieve access to justice, judges inevitably will play a crucial role. Without leadership from individual judges, and the judiciary collectively, the ideals of meaningful access to justice and equal justice under the law will remain aspirational, with little hope of their becoming reality.

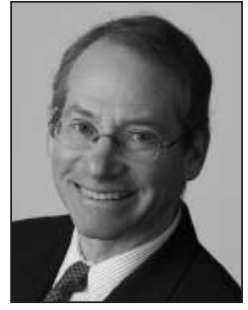

Professor Russell Engler directs the clinical programs for New England Law/Boston and serves as advisor for its Public Interest Law concentration. He writes about ethical issues, the delivery of legal services to the poor, Civil Gideon, and legal education. He directs the Public Service Project of the law school's Center for Law and Social Responsibility. Before joining the New England Law faculty in 1993, he was the director of the Housing Law Unit at Brooklyn (New York) Legal Services. He clerked for the Honorable Francis D. Murnaghan, Jr., of the U.S. Court of Appeals for the Fourth Circuit. During the 1999-2000 academic year, he was a lecturer on law at Harvard Law School. Professor Engler serves on the Massachusetts Access to Justice Commission and is a member of the Steering Committee for the National Coalition for a Civil Right to Counsel.

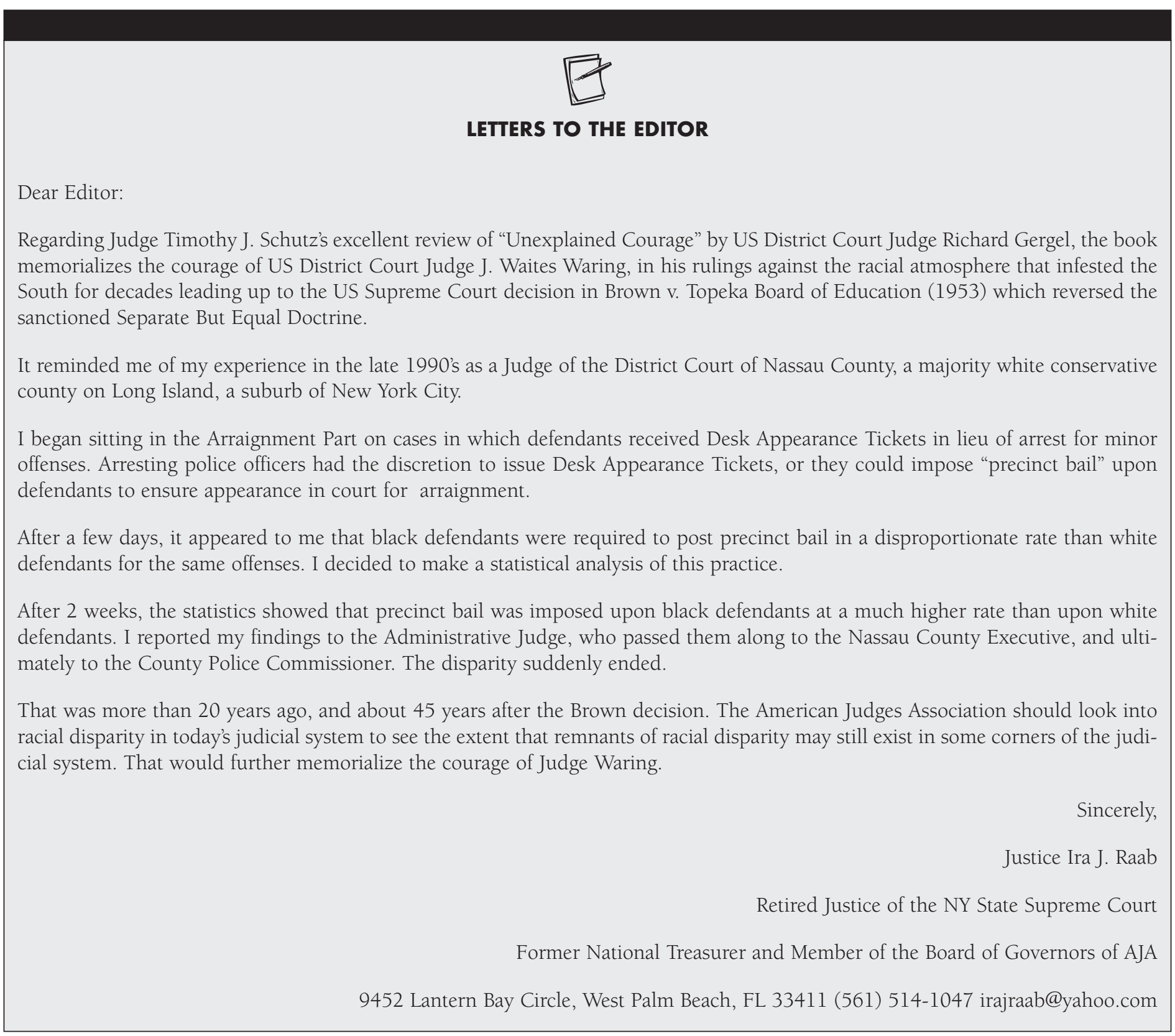

